\title{
Effects of Gonadotropin Releasing Hormone and Prostaglandin F2 Alpha ( $\alpha$ ) on Postpartum Reproductive Fertility in Black Bengal Goat (Capra bircus)
}

\author{
Azizunnesa ${ }^{1}$, Tapas Roy Barman ${ }^{1}$, AHM Musleh Uddin ${ }^{2}$, Md Moktadir Billah Reza ${ }^{1}$, Tanjila \\ HASAN $^{*}$
}

${ }^{1}$ Department of Medicine and Surgery, Faculty of Veterinary Medicine, Chattogram Veterinary and Animal Sciences University, Chattogram-4225, Bangladesh; ${ }^{2}$ Department of Surgery and Theriogenology, Faculty of Veterinary, Animal and Biomedical Sciences, Sylhet Agricultural University, Sylhet-3100, Bangladesh.

\begin{abstract}
A total of 45 postpartum goats were included and allocated into three experimental groups, 15 goats each. Group I was treated with single dose of GnRH (100 $\mu$ g/goat) at 10-14 days postpartum and PGF2 $\alpha$ (125 $\mu \mathrm{g} /$ goat $)$ at 20-24 days postpartum. Group II was treated with only PGF2 $\alpha(125 \mu \mathrm{g} / \mathrm{goat})$ at $20-24$ days postpartum. Group III was kept as a control group. Serum samples were collected from each group to determine the progesterone concentration. Experimental goats were observed for estrus detection regularly. Shorter uterine involution and kidding interval, minimum service per conception, and highest conception rate was significantly $(p \leq 0.05)$ found in group I compared with group II and group III. Progesterone level was significantly $(p \leq 0.05)$ increased in group I in contrast with group II and group III. Current findings revealed that combined use of GnRH and PGF2 $\alpha$ made an effective combination for the reduction of postpartum intervals and furthermore, to improve postpartum fertility.
\end{abstract}

Keywords | GnRH, PGF2 $\alpha$, ELISA, Progesterone, Black Bengal Goat

Received | January 14, 2021; Accepted | April 29, 2021; Published | July 28, 2021

*Correspondence | Tanjila Hasan, Department of Medicine and Surgery, Faculty of Veterinary Medicine, Chattogram Veterinary and Animal Sciences University, Chattogram-4225, Bangladesh; Email: tanjila88cvasu@gmail.com

Citation | Azizunnesa, Uddin AHMM, Reza MMB, Hasan T (2021). Effects of gonadotropin releasing hormone and prostaglandin F2 alpha ( $\alpha$ ) on postpartum reproductive fertility in Black Bengal Goat (Capra hircus). Adv. Anim. Vet. Sci. 9(9): 1437-1441.

DOI | http://dx.doi.org/10.17582/journal.aavs/2021/9.9.1437.1441

ISSN (Online) | 2307-8316; ISSN (Print) | 2309-3331

Copyright $\odot 2021$ Hasan et al. This is an open access article distributed under the Creative Commons Attribution License, which permits unrestricted use, distribution, and reproduction in any medium, provided the original work is properly cited.

\section{INTRODUCTION}

$\mathrm{B}$ lack Bengal goat (Capra hircus) is considered a native goat breed available in Bangladesh and northeastern India (Chowdhury et al., 2019). It contributes to the second position in terms of meat, milk, and skin production from livestock (Chowdhury, 2015; Siddiki et al., 2019).

Reproduction plays a vital role in the efficiency of economic purposes in goat farming. Several genetic, environmental and physiological factors are related to the reproductive soundness of goats. Normal postpartum period (PP) (69 \pm 7 days) is consists of both anatomic and physiologic re-adjustments of the uterus and endocrine system that is considered as a crucial factor for the recrudescence of reproductive capacity and regular cycling of a breeding goat (Greyling, 2000; Moni and Samad, 2019). Complete re-adjustments of the postpartum uterus and resumption of sexual activity following parturition in ruminants normally depends on several factors, such as nutrition, nursing of offspring, and season of parturition (Zongo et al., 2014). Even though, any delay in postpartum uterine and ovarian involution of farm animals exerts a limitation on reproductive performance following parturition (Degefa et al., 2006). Consequently, early occurrence of heat in post-partum animals following uterine and ovarian involution is mandatory 
to maximize reproductive performance as well as production (Ibrahim, 2000). Numerous research has been directed to study the interval between parturition and the first postpartum estrous in goats (Greyling, 2000). The longer postpartum interval can be reduced by some hormonal treatment in ruminants (E1 Tahawy and Sharkawy, 2014). Goat's become responsive to exogenous $\mathrm{GnRH}$ as early as the first week postpartum (Elsheikh et al., 2013). Gonadotropin releasing hormone treatment after parturition can reduce the duration of the postpartum anestrus period in cows (E1 Tahawy and Sharkawy, 2014). The prolonged postpartum period due to failure of resumption of ovarian activity can be corrected with the use of GnRH in the goat. Injection of $\mathrm{GnRH}$ during the first week postpartum in Nubian goats induces first postpartum estrus and increase conception rate by enhancing early uterine involution (Elsheikh et al., 2013). Another hormone called PGF2 $\alpha$ is also used to reduce the postpartum period in cows through luteolytic effects (Elsheikh and Elzubeir, 2004). Hence, estimation of progesterone levels during different physiological stages of animals is an important tool to determine their fertility status (Khanum et al., 2008). As far we know that no report on the uses of PGF $2 \alpha$ for the reduction of the PP period in Black Bengal goats in Bangladesh. Therefore, the study on hormonal treatment protocol in postpartum goat is badly needed in postpartum period. Findings from this study would be beneficial for the farmers as they will get more benefits by follow studied treatment. Moreover, the study was designed with aimed to find out the efficacy of $\mathrm{GnRH}$ and PGF2 $\alpha$ on early postpartum uterine involution along with their effects on progesterone level in postpartum goats.

\section{MATERIALS AND METHODS}

\section{AnIMALS}

45 post-partum Black Bengal goats (within 24 days of kidding) were selected for this study. The study was conducted in the Chittagong Metropolitan area of Chittagong district. Hormonal tests were performed in the Laboratory of Andrology, Faculty of Veterinary Medicine, Chittagong Veterinary and Animal Sciences University (CVASU).

\section{Data Collection}

Age, parity, body condition score (BCS), feeding regimens, deworming and, vaccination history and last delivery information was recorded by questionnaire through face to face interview with owners. Reproductive parameters like postpartum period, days to first mating, service per conception, conception rate and kidding interval, etc. were also recorded.

\section{EXPERIMENTAL LAYOUT}

45 goats were divided into three subgroups as Group-I
Group-II and Group-III. Each group contains 15 goats. Group-I was an experiment with GnRH (Fertilon ${ }^{\circledR}$ synthetic Gonadorelin, Techno Ltd. BD) of a dose of $100 \mu \mathrm{g} /$ goat at 10-14 days of PP and PGF2 $\alpha$ (Prostenol ${ }^{\circledR}, \mathrm{Clo}^{-}$ prostenol Sodium, Techno Ltd. BD) of a dose of $125 \mu \mathrm{g} /$ goat at 20-24 days of PP. Group II ( $n=15)$ was an experi-

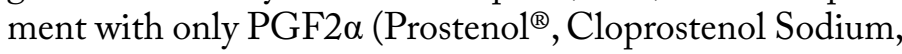
Techno Ltd. BD) of a dose of $125 \mu \mathrm{g} /$ goat at 20-24 days PP. Group-III was used as a control group to rear natural habitation.

\section{Estrus Detection}

Clinical estrous signs such as tail wagging, bleating, frequent urination, mock fighting, licking and rubbing each other, increased vocal activity, hyperemia and edema of the vulva, and vaginal mucus discharge were observed by owners in experimental goats twice daily at $6.00 \mathrm{a}$.m. and 4.00 p.m. (Fakruzzaman et al., 2012). After 10 days postpartum, active and sound bucks were mixing with the female goats (Fakruzzaman et al., 2012). During estrous, the female goat allow mounting by Bucks (Elsheikh et al., 2013).

\section{Collection of Blood Samples}

$3 \mathrm{ml}$ blood was collected from the jugular vein of every single experimental goat after 3 days of each treatment. Each blood sample was allowed to clot for 1 hour at room temperature (Perry et al., 2019; Tuck et al., 2009). The serum was separated by centrifugation at $1000 \mathrm{~g}$ for 10 minutes, transferred to $1.5 \mathrm{ml}$ micro-centrifuge tubes, and stored at $-20^{\circ} \mathrm{C}$ until used for hormone analysis.

\section{Progesterone Assay}

The concentration of progesterone was measured by progesterone ELISA kit (JAJ International, Inc, medical diagnostic manufacturer, USA) using procedures recommended by the manufacturer (Aufrère and Benson, 1976). Absorbance was measured at $450 \mathrm{~nm}$ with a micro titter well reader within 15 minutes.

\section{Statistical Analysis}

The data were analyzed using the statistical software program SPSS 22.0 for Windows 10. The normality test of data was done by the Kolmogorov-Smirnov test (Steinskog. et al., 2007). One way ANOVA test was performed among three treatment groups (Zimmerman and Zumbo, 1993). Chi-Square test with Fisher's exact test was done to calculate the reproductive parameters (Hopkins, 1978). Significant was considered at $p \leq 0.05$ (Rice, 1989).

\section{RESULTS AND DISCUSSION}

Hormonal treatment at the postpartum period in Black Bengal goat influenced the reproductive performances with increasing progesterone concentration in blood. The 
study was conducted to observe the effects of $\mathrm{GnRH}$ with PGF2 $\alpha$, and single PGF2 $\alpha$ at two different times at postpartum in goats. Uterine involution, service per conception, and kidding intervals were significantly $(p \leq 0.05)$ shorter in Group I compared with Group II and Group III (Table 1). The conception rate was higher in Group I in comparison to Group II and Group III that was statistically significant $(p \leq 0.05)$ (Table 1).

Table 1: Effects of hormones (GnRH and PGF2 $\alpha$; and $P G F 2 \alpha)$ in post-partum reproductive parameter among three experimental group.

\begin{tabular}{|c|c|c|c|}
\hline \multirow[t]{2}{*}{ Parameters } & \multicolumn{3}{|c|}{ Group of animals } \\
\hline & Group - I & Group-II & $\begin{array}{l}\text { G ro u p - I I I } \\
\quad \text { (control) }\end{array}$ \\
\hline $\begin{array}{l}\text { Uterine involu- } \\
\text { tion (days) }\end{array}$ & $56.05 \pm 17.63^{a}$ & $68.53 \pm 15.4^{\mathrm{bc}}$ & $73.53 \pm 11.58^{c}$ \\
\hline $\begin{array}{l}\text { Service per } \\
\text { conception }\end{array}$ & $1.40 \pm 2.07^{\mathrm{a}}$ & $1.73 \pm 1.73^{\mathrm{ab}}$ & $2.07 \pm 0.80^{\mathrm{b}}$ \\
\hline Conception rate & $93.4^{a}$ & $80^{\mathrm{bc}}$ & $73.4^{\mathrm{c}}$ \\
\hline $\begin{array}{l}\text { Kidding inter- } \\
\text { val (days) } \\
\text { Superscript letter } \\
\text { at } p \leq 0.05 \text {. }\end{array}$ & $218.47 \pm 23.42^{a}$ & $239.53 \pm 29.78^{\mathrm{bc}}$ & $254.33 \pm 23.42^{c}$ \\
\hline
\end{tabular}

GnRH with PGF2 $\alpha$ was used to increase reproductive performance in animals including goats (Elsheikh et al., 2013). Group I treatment the GnRH with PGF2 $\alpha$ initiates in a regular estrous cycle with subsequently positive effects in uterine involution, service per conception, kidding intervals, and conception rate respectively. The results were agreed with Panicker et al. (2015) and Holtz et al. (2008). Uterine involution and estrus cycle is associated with the GnRH concentrations after postpartum and the first ovulation followed by a normal luteal phase (Elsheikh et al., 2013). PGF2 $\alpha$ enhances uterine involution rate by direct ecobolic effect on the uterus that increases the tone of the uterine muscle. It also stimulates uterine smooth muscle in absence of a luteal structure that aggravates uterine involution and postpartum estrus (Elsheikh et al., 2013). The mean postpartum intervals $(68.53 \pm 15.40$ days $)$ of does in our study was very close to the Nubian Goats treated with PGF2 $\alpha$ immediately after kidding (first week) were reported as $(61 \pm 0.71)$ days (Elsheikh et al., 2013). However, the author used the drugs at the first week of calving, while, in the present study it was used at 20-24 days ( $3^{\text {rd }}$ week) postpartum (Elsheikh et al., 2013).

Our findings revealed that exogenous GnRH and PGF2 $\alpha$ administered in goat (Group I) during the early postpartum period significantly $(p \leq 0.05)$ decreased kidding intervals followed by Group II and Group III. It possesses similarity with Wright et al. (1981) who reported that kidding interval was lowest in does treat with GnRH with PGF2 $\alpha$. These findings were also agreed with the previous results reported by Ibrahim, (2000). Administration of GnRH in animals is reported to induce postpartum ovarian cyclicity and having indirect and/or direct activity on the ovarian functions (Elsheikh et al., 2013). Consequently, service per conception in group III was statistically higher than group I and group II $(p \leq 0.05)$. This result indicated that GnRH treated goats performed less number of services to ensure their ultimate conception. This finding was in agreement with Takayama et al. (2010). In conception rate, the highest rate was found in Group I compared with Group II and Group III. Our reports supported by Zonturlu et al. (2018). This result revealed that GnRH hormone also prevent embryonic and foetal loss or to increase reproductive performance in goat and sheep (Zonturlu et al., 2018). The variations of the study might be due to differences in breed, management, treatment method used, or epidemiological factors.

After the treatment of GnRH and PGF2 $\alpha$ in experimental goats, progesterone level was significantly $(p \leq 0.05)$ increased in Group I compared to Group II and Group III (Table 2).

The $\mathrm{P}_{4}$ profile is an indicator for the recurrence of postpartum estrus in goats (Elsheikh et al., 2013). The concentration of progesterone in the blood is a crucial key to study luteal functions during the postpartum period. The $\mathrm{P}_{4}$ concentration in the peripheral circulation does not exceed 0.6 $\mathrm{ng} / \mathrm{ml}$ until the time of ovulation (El-Naiem 2003). The concentration of serum $\mathrm{P}_{4}$ in group I was higher $(0.48 \pm$ $0.12 \mathrm{ng} / \mathrm{ml}$ ) in comparison with the control group, Group III $(0.35 \pm 0.09 \mathrm{ng} / \mathrm{ml})$. Subsequently, days $20-24 \mathrm{PP}$ after PGF2 $\alpha$ administration in group I the $\mathrm{P}_{4}$ concentration was higher $(0.6 \pm 0.11 \mathrm{ng} / \mathrm{ml})$ compared with control does

Table 2: Effects of hormones ( $\mathrm{GnRH}$ and PGF2 $\alpha$; and PGF2 $\alpha$ ) in progesterone level $\left(\mathrm{P}_{4}\right)$ during postpartum period among three experimental group.

\begin{tabular}{|c|c|c|c|c|}
\hline $\begin{array}{l}\text { Treatment } \\
\text { groups (n) }\end{array}$ & $\begin{array}{l}\text { Treatment time } \\
\text { (10-14 d of PP) }\end{array}$ & $\begin{array}{c}P_{4} \text { level (10-14 days) } \\
\mathrm{ng} / \mathrm{ml}\end{array}$ & $\begin{array}{l}\text { Treatment time } \\
\text { (20-24d of PP) }\end{array}$ & $\underset{4}{\mathrm{P}_{4} \text { level (20-24 days) } \mathrm{ng} /}$ \\
\hline Group I & GnRH & $0.48 \pm 0.12^{\mathrm{a}}$ & PGF2 $\alpha$ & $0.6 \pm 0.11^{\mathrm{a}}$ \\
\hline Group II & - & $0.41 \pm 0.13^{\mathrm{ab}}$ & PGF $2 \alpha$ & $0.53 \pm 0.17^{a}$ \\
\hline Group III & - & $0.35 \pm 0.09^{b}$ & - & $0.44 \pm 0.09^{b}$ \\
\hline
\end{tabular}

$\mathrm{PP}=$ Postpartum period, $\mathrm{P}_{4}=$ Progesterone level, Superscript letter $\mathrm{a}, \mathrm{b}$ indicate significant difference with group at $p \leq 0.05$. 
$(0.44 \pm 0.09 \mathrm{ng} / \mathrm{ml})$. These results were in agreement with the findings of El-Naiem (2003). The $\mathrm{P}_{4}$ level increased slowly from day $7(0.54 \pm 0.2 \mathrm{ng} / \mathrm{ml})$ and reached a peak level on day 27 of pp $(0.87 \pm 0.4 \mathrm{ng} / \mathrm{ml})$ and then declined rapidly to the minimum level on day 31 postpartum (Khanum et al., 2007). These results were also slightly higher than the present findings. El-Naiem (2003) reported the basal level of serum $\mathrm{P}_{4}$ after treatment with PGF2 $\alpha$ at third week postpartum was $0.49 \mathrm{ng} / \mathrm{ml}$ in a study.

\section{CONCLUSIONS}

Administration of $\mathrm{GnRH}$ between 10-14 days followed by PGF $2 \alpha$ between 20-24 days of postpartum influenced early postpartum cyclicity in goats. This treatment also influenced the blood progesterone in postpartum goats that accelerated early postpartum estrus. We can conclude that combined use of GnRH and PGF2 $\alpha$ triggers a fundamental paddle for the reduction of postpartum intervals and subsequent, to improve the reproduction of goats.

\section{ACKNOWLEDGEMENTS}

The authors would like to acknowledge the Dept. of Medicine and Surgery and Shahidul Alam Quadery Teaching Veterinary Hospital (SAQTVH), Chittagong Veterinary and Animal Sciences University (CVASU) for their support to carry out the study.

\section{AUTHOR CONTRIBUTIONS}

TH and $\mathbf{A}$ conceived and designed the experiment, $\mathbf{T H}$ and MMBR conducted collection and analyzed the samples, AHMMU and TH conducted data management, all authors contributed to write and review of the final manuscript.

\section{CONFLict OF INTERESTS}

The authors declare that there is no conflict of interest.

\section{FUNDING INFORMATION}

The project was funded by the National Science and Technology (NST) Fellowship, Ministry of National Science and Technology, Dhaka, Bangladesh.

\section{REFERENCES}

-Aufrère MB, Benson H (1976). Progesterone: an overview and recent advances. J. Pharm. Sci. 65(6):783-800. https://doi. org/10.1002/jps.2600650602

- Chowdhury SD (2015). Study on Goat Value Chain in Bangladesh. Final Report, Heifer International Bangladesh, Dhaka, Bangladesh.

- Chowdhury SMZH, Nazir KHMNH, Hasan S, Kabir A, Mahmud MM, Robbani M (2019). Whole genome analysis of Black Bengal goat from Savar Goat Farm, Bangladesh. BMC Res. Notes. 12(1):10-14. https://doi.org/10.1186/ s13104-019-4700-7

-Degefa T, Ababneh MM, Moustafa MF (2006). Uterine involution in the post-partum Balady goat. Vet. Arh. 76(2):119-133.

-El-Naiem WM (2003). The progesterone profile of the caprine oestrous cycle and luteolysis as induced by castor oil (Ricinus commums) seeds fed to cyclic goats (Capra Hircus). PhD thesis, Faculty of Agricultural Sciences University of Giezira, Sudan.

-E1 Tahawy AS, Sharkawy A (2014). The Influence of Different Hormonal Therapies on the Reproductive, Productive and Economic Efficiency of Early Postpartum Dairy Cows. J. Dairy. Vet. Anim. Res. 1(2):46-54. https://doi.org/10.15406/ jdvar.2014.01.00011

-Elsheikh AS, Elzubeir FOA (2004). The Effect of Administration of PGF2 during Early Postpartum on Reproductive Efficiency of Cross-bred Dairy Cows in the Sudan. J. Anim. Vet. Adv. 3(8):497-502.

-Elsheikh AS, Nour Eldaim NO, Alqurashi AM (2013). Management of Postpartum Interval of Nubian goats with PGF2 $\alpha$ and GnRH. J. Am. Sci. 9(3):181-184.

-Fakruzzaman M, Akter QS, Husain SS, Islam MR (2012). Estrus Characteristics of Black Bengal Does Under Intensive Condition. Iran. J. Appl. Anim. Sci. 2(1):89-95.

- Greyling JPC (2000). Reproduction traits in the Boer goat doe. Small Rumin. Res. 36(2):171-177. https://doi.org/10.1016/ S0921-4488(99)00161-3

- Holtz W, Sohnrey B, Gerland M, Driancourt MA (2008). Ovsynch synchronization and fixed time insemination in goats. Theriogenology. 69:785-792. https://doi. org/10.1016/j.theriogenology.2007.10.004

-Hopkins KD (1978). Applicability of chi-square to $2 \times 2$ contingency tables with small expected cell frequencies. Psychol. Bull. 85(1):163-167. https://doi.org/10.1037/00332909.85.1.163

-Ibrahim MT (2000). Studies on some reproductive parameters of Nubian goats and their Sannen cross breeds under local environmental conditions. PhD Thesis, Faculty of animal production University of Khartoum, Sudan.

-Khanum SA, Hussain M, Kausar R (2007). Assessment of reproductive parameters in female Dwarf goat (Capra hircus) on the basis of progesterone profiles. Anim. Reprod. Sci. 102(3-4): 267-275. https://doi.org/10.1016/j. anireprosci.2006.11.010

-Khanum SA, Hussain M, Kausar R (2008). Progesterone and estradiol profiles during estrous cycle and gestation in Dwarf goats (Capra hircus). Pak. Vet. J. 28(1): 1-4.

- Moni MIZ, Samad MA (2019). Evaluation of productive and reproductive performances of black bengal goats in rajshahi government goat development farm in Bangladesh. J. Vet. Med. OH. Res. 1(2):201-210. https://doi.org/10.36111/ jvmohr.2019.1(2).0012

- Panicker SS, Kanjirakuzhiyil P, Koodathil R, Kanakkaparambil $\mathrm{R}$ (2015). Oestrus response and conception rate in malabari cross bred goats following two different oestrus synchronization protocols. J. Anim. Health. Prod. 3(2): 3942. https://doi.org/10.14737/journal.jahp/2015/3.2.39.42

- Perry JN, Jasim A, Hojat A, Yong WH (2019). Procurement, storage, and use of blood in biobanks. Methods Mol. Biol. 1897: 89-97. https://doi.org/10.1007/978-1-4939-89355_9 
- Rice WR (1989). Analyzing tables of statistical tests. Evolution. 43(1):223-5. https://doi.org/10.1111/j.1558-5646.1989. tb04220.x

- Siddiki AZ, Baten A, Billah M, Alam MAU, Shawrob KSM, Saha S (2019). The genome of the Black Bengal goat (Capra hircus). BMC Res. Notes. 12(1):362. https://doi. org/10.1186/s13104-019-4400-3

- Steinskog DJ, Tjøstheim DB, Kvamstø NG (2007). A cautionary note on the use of the Kolmogorov-Smirnov test for normality. Mon. Weather. Rev. 135(3):1151-1157. https:// doi.org/10.1175/MWR3326.1

- Takayama H, Tanaka T, Kamomae H (2010). Postpartum ovarian activity and uterine involution in non-seasonal Shiba goats, with or without nursing. Small Rumin. Res. 88(1):6266. https://doi.org/10.1016/j.smallrumres.2009.11.001

- Tuck MK, Chan DW, Chia D, Godwin AK, Grizzle WE, Krueger KE (2009). Standard operating procedures for serum and plasma collection: early detection research network consensus statement standard operating procedure integration working group. J. Proteome. Res. 8(1):113-117.

https://doi.org/10.1021/pr800545q

-Wright RWJr, Bondioli K, Grammer J, Kuzan F, Menino AJr (1981). FSH or FSH plus LH superovulation in ewes following estrus synchronization with medoxyprogesterone acetate pessaries. J. Anim. Sci. 52:115-118.

-Zimmerman DW, Zumbo BD (1993). Relative power of the Wilcoxon test, the Friedman test, and repeated-measures ANOVA on ranks. J. Exp. Educ. 62(1):75-86. https://doi.org /10.1080/00220973.1993.9943832

-Zongo M, Traoré B, Ababneh MM, Hanzen C, Sawadago L (2014). Ultrasonographic assessment of uterine involution and ovarian activity in West African Sahelian goats. J. Vet. Med. Anim. Heal. 7(2):71-76. https://doi.org/10.5897/ JVMAH2014.0322

-Zonturlu AK, Kaçar C, Kaya S, Emre B, Korkmaz O, Ari UC (2018). Effect of double GnRH injections on reproductive parameters in Awassi ewes receiving long-term progesterone. J. Appl. Anim. Res. 46(1):1103-1107. https://doi.org/10.108 0/09712119.2018.1469497 